\title{
Ragam Hias Mirong Simbol Kebesaran dan Kepemilikan Bangunan Milik Raja Kasultanan Yogyakarta
}

${ }^{1}$ Sukirman

\begin{abstract}
Abstrak
Bangunan Rumah Tradisional Keraton Yogyakarta banyak yang dihiasi khususnya menggunakan ornamen tradisional Jawa berupa stilirisasi bentuk tumbuh-tumbuhan. Diantara ragam hias mirong, yang bila melihat bentuknya bukan stilirisasi tumbuhan. Tidak terdapat dokumen yang menyertai proses pembuatan ragam hias mirong yang menerangkan makna dan artinya, sehingga muncul berbagai persepsi tentang mkana dan arti ragam hias mirong. Satu diantaranya mirong sebagai perwujudan Ratu Kidul (penguasa laut selatan). Di samping untuk menghias beberapa bangunan di dalam keraton mirong juga dipergunakan untuk menghias bangunan Masjid Agung Yogyakarta, yang menjadi persoalan, relevankah pemaknaan bahwa mirong sebagai perwujudan Ratu Kidul (Penguasa Ratu Selatan). Masyarakat awam belum tahu makna dan artinya, padahal mirong merupakan bagian dari karya, cipta, rasa, dan karsa Keraton Yogyakarta yang merupakan ciri khas dan identitas bangunan, ragam hias dan budaya Keraton.
\end{abstract}

Kata Kunci: Mirong, Keraton, masjid, Ratu Kidul

\section{Pendahuluan}

Di Yogyakarta banyak dijumpai ragam hias atau ornament tradisional, baik ragam hias pada pekerjaan batik, tekstil, barang kerajinan lainnya, ragam hias pada percandian, maupun pada bangunan rumah. Ragam hias digolongkan sebagai benda seni, ragam hias merupakan produk seni, termasuk seni kerjinan, maka ragam hias harus artistik, atau indah. Ragam hias dapat digolongkan ke dalam seni kerajinan, karena merupakan perpaduan antara aspek artistic dengan aspek ketrampilan atau kemahiran diholongkan juga kedalam seni dekorasi karena ragam hias mempunyai fungsi menghias. Melihat berbagai penggolongan tersebut, maka ragam hias termasuj juga seni terapan, karena diterapkan pada berbagai benda.

Pecahnya Keraton Mataram melalui Perjanjian Giyanti pada tahun 1575 menjadi Kasunanan Surakarta dan Kasultanan Yogyakarta, Merupakan babak baru mengawali berdirinya Keraton Kasunanan Surakarta dan Kasultanan Yogyakarta. Mulai dari peristiwa itu pula maka mengawali langkah dan gerak Keraton Yogyakarta untuk menunjukkan eksistensi dan karakteristik Keraton Yogyakarta sebagai pusat pemerintahan dan sebagai pusat budaya. Semangat berkarya berkembang dengan pesat budaya berdasarkan pengembangan cipta rasa dan karsa Keraton Yogyakarta sebagai lembaga pemerintahan, pusat pengembangan adat istiadat, seni dan budaya, senantiasa eksis dan mandiri memperkokoh identitasnya dalam berbagai hal sehingga tampil berbeda dengan keraton-kearton lain, termasuk berbeda dengan Keraton Kasunanan Surakarta yang sama-sama merupakan pecahan ari Keraton Mataram.

Sepanjang perjalanan Keraton Yogyakarta telah menghasilkan berbagai keagungan karya-karyanya baik karya tari, sastra, busana, kerajinan, arsitektur, adat istiadat, dan masih banyak lagi yang semuanya berkarakter dan berciri khas Yogyakarta. Dalam bidang seni tari Keraton Yogyakarta telah menghasilkan beberapa tari yang terkenal, antara lain tari yang terkenal antara lain serimpi, tari bedoyo dan sebagainya. Dalam bidang kerajinan batik terdapat berbagai jenis busana tradisional khas Yogyakarta. Dalam bidang arsitektur, telah dikembangkan bentuk bangunan rumah joglo, di antaranya bentuk bangunan rumah tradisional berbentuk joglo lambang gantung, bahkan merupakan perkembangan bentuk rumah tradisional yang terakhir. Berbagai bangunan Keraton dengan mengadopsi bangunan-bangunan colonial dengan berbagai penyesuaian dengan karakter bangunan setempat, termasuk melengkapi karakterisitik bangunan Yogyakarta. Dalam bidang music tradisoional, misalnya 
gending-gending Jawa, dalam bidang pewayangan juga terdapat pengembangan yang hasilnya menunjukkan perbedaan dengan wayang-wayang gaya Surakarta.

\section{Ragam Hias Mirong}

Diantara berbagai hasil karya, Keraton terdapat terdapat beberapa gaya dan corak ragam hias yang khas menghiasi berbagai bangunan rumah joglo yang berfungsi sebagai bangsal.

Diantara 


\section{Metode}

Metode menuliskan bagaimana cara penelitian dilakukan baik penelitian kualitatif dan kuantitatif dijelaskan secara ringkas dan jelas.

2. Hasil dan Pembahasan

Hasil dan pembahasan ditulis dengan alur yang jelas disertai dengan tabel dan gambar sebagai pendukung dari hasil pembahasan. Penulisan tabel menggunakan judul di bagian atas tabel sedangkan gambar di bawah gambar seperti contoh di samping. Analisis dan pembahasan tidak lebih dari 8 kolom (4 halaman).

3. Kesimpulan dan Masukan

Kesimpulan dituliskan dengan menjabarkan hasil dari diskusi dan pembahasan yang sudah dituliskan bab sebelumnya. Dengan memberikan arahan dan masukan kedepannya jika diperlukan. Tidak lebih dari 2 kolom (1 halaman)

Silahkan kirimkan tulisan ini ke Jurnal Pendapa dengan alamat email :

arsitektur.uwm@gmail.com

\section{Referensi}

Ditulis dengan gaya APA (American Psychological Association) dengan contoh seperti di bawah dan ditulis tidak lebih dari 2 kolom (1 halaman)

Rapoport, Amos. 1977. Human Aspects of urban Form, Towards a man-Environment Approach to Urban Form and Design.New York: Pergamon Press

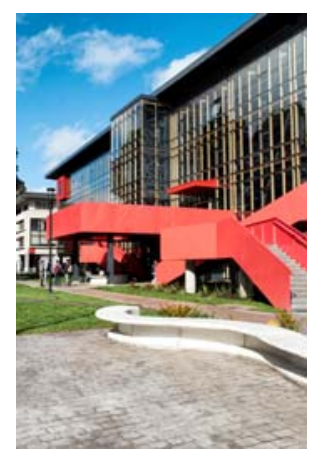

Gambar 1.1 K Building, School of Architecture and Construction Autonomous University of Chile / Schmidt Restrepo Arquitectos (Sumber:www.archdaily.com) Sertakan sumber yang valid missal: Penulis, 2019

Lima komponen di atas harus terpenuhi sesuai dengan struktur IMRAD (Introduction, Methods, Result, Discussion) Total halaman minimal 6 maksimal 15. 